\title{
ENTREPRENEURIAL EDUCATION IN AUTOMOBILE TECHNOLOGY AS A PANACEA FOR ADDRESSING UNEMPLOYMENT AMONG GRADUATES IN NIGERIA
}

\section{ABDULKADIR, M. AND ALAWODE, O. D.}

\section{Abstract}

Millemium Development Goals are the most broadly supported, comprehensive and specific development goals the world has ever agreed upon. These goals provide concrete, numerical benchmark for alleviating extreme poverty in its many dimensions. However, political instability and inconsistencies in the socio-economic policies of government led to the emergence of high level of umemployment in Nigeria with its attendance consequences on the attainment of MDGs. This paper therefore focuses attention on entrepreneurial education in automobile technology as a panacea for addressing unemployment among graduates. The paper examined the concept of entrepreneurship, entrepreneurship education as well as entrepreneurship skills in automobile technology for the attainment of MDGs. It was recommended that Curriculum should be reviewed to include entrepreneurship as part of technology education which automobile technology is an integral part of, so that the products do not only strive for self-employment and self-reliant but be self employed, Entrepreneurial skills should be encouraged through the mass media and emphasis should be placed on practical institutional delivery in automobile technology programme with equal emphasis on learner's activities in every unit of the programme.

\section{Introduction}

Several nations today are faced with different magnitudes of problems, which involves social, political as well as education problems. However, in the words of Adetayo (2009) inflation, political instability, ethnic crisis, over population and unemployment are also problems. Unemployment has continued to increase to a greater dimension most especially among graduates of Universities, Polytechnics, Colleges of Education and other institutions of higher learning. Ozohu (2011) lamented that unemployment has become a global socio-economic problem that prevails among Nigeria youths. Most of youths in Nigeria depend solely on white collar jobs which according to Olatunji (2007) have now become a mirage.

Unemployment is simply a situation where people who are willing and able to work cannot find any work to do. Unemployment in Nigeria is a serious problem since this contributes to increase in different kinds of crimes.
One major cause of unemployment is the one arising through Nigeria's present educational system where "white collar" job seekers produced through Nigeria's type of educational system, the type inherited from colonial masters that do not prepare students for acquisition of skills that could equip them for self employment after schooling (Adetayo, 2009). The increase in number of schools established as well as in the explosion in student enrolment has made unemployment inevitable since there is no corresponding increase in the number of jobs created in the country. According to Arogundade (2011) political instability and inconsistencies in the socio-economic policies of successful governments led to the emergence of high level unemployment in Nigeria. Akinbayo (1987) and Raheem (1993) opined that unemployment is one of the serious impediments to social progress. They further argued that apart from representing a colossal waste of country's manpower resources, it generates welfare loss in terms of 
output thereby leading to lower income and well-being. Unemployment is a very serious issue in Africa (Vandemoortele, 1991 and Rama, 1998) and particularly in Nigeria (Oladeji, 1994 and Umo, 1996).

It can therefore be seen that there is a problem of job creation, also there is need for the inculcation of self employment or entrepreneurial skills into Nigerian graduates or youths as unemployment reduction measure. A re-orientation of Nigeria's educational system through an entrepreneurial based curriculum could be used to achieve this laudable goal of unemployment reduction and job creation skills among graduates or youths in Nigeria.

\section{Entrepreneurship \\ Entrepreneurship Education}

and

Entrepreneurship can simply be explained as a clear manifestation of manipulative skills of an individual intelligence as demonstrated in creative performance. It can further be defined as an innovating individual who has developed an ongoing business activity where none existed. Olutoyin (2009) sees an entrepreneur as a person who organizes and manages business, under takes and assumes a risk for the sake of profit. He or she tends to start ventures that build on specific skills they have already acquired through formal education or in certain occupation or industry. An entrepreneurship is a process of bringing together the factors of production which include land, labour and capital so as to provide a product or service for public consumption. Therefore it can be inferred that entrepreneurship is the willingness and ability of person or persons to acquire educational skills to explore and exploit investment opportunities, establish and manage a successful business enterprise. All together these can only be achieved through effective teaching and learning of entrepreneurship education in Nigeria institutions of learning.

Entrepreneurship education is the education that provides skill for individuals and the ability to recognize opportunities that others have over looked and to have insight, self-esteem and knowledge to act where others have hesitated. Entrepreneurship education is all about increasing student's ability to anticipate and respond to societal changes. Entrepreneurial education is very important because it has social and economic values. It helps prepare the individual to be self employed and for life. Entrepreneurial education provides the education that will help foster the development of small and medium enterprise that are crucial in promoting economic development as well as alleviating poverty. Entrepreneurship education is a carefully planned process leading to the acquisition of entrepreneurship skills for effective living. According to Elechi (2009) entrepreneurship education is an instrument that empowers youth to be in control of their future. Paul (2005) however stressed that entrepreneurship education is structured to achieved the following objectives:

1. To offer functional education for the youth that will enable them to be self-employed and self-reliant.

2. Provide the youth graduates with adequate training that will enable them to be creative and innovative in identifying novel business opportunities.

3. To serve as a catalyst for economic growth and development.

4. Offer tertiary institution graduates with adequate 
training in risk management, to make certain bearing feasible.

5. To reduce high level of poverty.

6. Create employment generation.

7. Reduction in rural-urban migration.

8. Provide the young graduates with enough training and support that will enable them to establish a career in small and medium sized businesses.

9. To inculcate the spirit of perseverance in the youths and adults which will enable them to persist in any business venture they embark on.

10. Create smooth transition from traditional to a modern industrial economy

\section{Entrepreneurship skills in Automobile Technology and the Attainment of MDGs}

Automobile Technology is one of the vocational technical education programmes which involve the acquisition of scientific knowledge in design, selection of materials, construction, operation and maintenance of motor vehicles. According to Doyin (2004) Automobile Technology is a vocational programme, and a vocational programme is all about preparing one for a specific occupation. Vocational programmes are generally designed to prepare individuals for a gainful employment as semi-skilled or skilled worker or technicians or sub-professional in recognized occupation and in new and emerging occupations or to prepare individual for enrolment in advanced technical education programme (Ugwaja,2010). It can be seen from the preceding analysis that certain _skill areas in automobile technology can be used to achieve Millennium
Development Goals (MDGs) in Nigeria.

The Millennium Development Goals (MDGs) are eight international development goals that all 193 United Nation members states and at least 123 international organizations have agreed to achieve by the year 2015 . The goals are: eradicating extreme poverty and hunger, achieving universal primary education, promoting gender quality and empowering women, reducing child mortality rates, improving maternal health, combating HIV/AIDS, malaria, and other diseases, ensuring environmental sustainability, and developing a global partnership for development. The goals according to Margrete (2009) are an unprecedented global commitment and one of the most significant United Nations documents of recent time. She further asserted that MDGs offer an integrated vision on how to tackle some of the major challenges facing the world. A very sight of the fact should not be loss here that these goals might remain elusive unless much emphasis is laid on the development of entrepreneurial skills. In view of this fact, this paper focuses attention on the entrepreneurial skills in automobile technology for eradicating extreme poverty and hunger in Nigeria which is one of the MDGs goals. Nwagbo and Onyegebu (2009) asserted that entrepreneurship skill will empower the students who are unable to further their education to live a better life. The following can integrate into the automobile technology curriculum under relevant themes:

1. Checking and topping up engine oil: This activity involves removing the dip stick, wipe it and replace it; then remove it again to see where the oil level comes in relation to the maximum and 
minimum marks. If it is only just above minimum then oil should be added through the filler almost located on top of the engine in the camshaft or rocker cover. Add a little oil at a time until the correct level is reached. Under this students should be encouraged to know that engine oil level must be kept up to the correct level, which is usually recorded on a calibrated dipstick inserted into the oil lump through the side of the engine or at the front of transverse unit.

2. Checking and topping up power steering fluid: Many cars are equipped with powerassisted steering and this is hydraulically operated. The reservoir for the hydraulic fluid is usually located on the pump, driven by a belt of the engine. The students should be made to understand that this reservoir should be kept topped up to the correct mark only with the recommended fluid. The students should be taught that low level of fluid in the reservoir will produce harder steering.

3. Maintaining tyre pressures: This involves using pressure gauge to determine the tyre pressure at regular interval. The students should be made to understand that it is important that the correct tyre pressure be adhere to; not only will incorrect settings alter the handling of a car, perhaps causing it to pull to one side, they may actually lead to damage to the tyres car casses.

4. Re-boring main and big-end bearings: This activity involves cleaning the faces or tightening the nuts and releasing one side. The bearing cap should spring away from the crankcase about 0.0002 inch, thus providing that the shells are being held by the cap. Finally clean the faces of the connecting rods, assemble, cheeking the fit of the rods, and the nip of the cap on the bearings when loose bearing shells are used. Under these activities, students should be made to understand that the following tools and equipment are required; external and internal micrometer, flat file, feeler gauge, cutting tools, connecting-rod boring jig and line boring equipment for main bearings.

5. Checking piston rings gaps: This operation or activity involves checking piston ring gap with a feeler gauge after the ring has been inserted into the cylinder and pushed squarely down about $5 \mathrm{~mm}$ with the piston.

6. Cleaning and changing air filter: All cars are fitted with an air filter to keep dirt out of carburetor intake. This filter can become clogged with dirt, restricting the passage of air to the engine. Though there are different versions of the air filter, therefore irrespective of any type, air filter should be checked, clean and replaced at regular interval.

7. Cooling system maintenance: The water level in the radiator should be checked frequently. Preferably remove the radiator cap when cold, but if the water is hot take the cap off slowly, protecting your hand with a cloth. Top up the system if necessary, but if there is a large loss suspect a leak and check 
the hoses. Occasionally the system should be drained and flushed. Under this activity, students should understand that low water level in the radiator will cause overheating of the engine which will in turn damage the cylinder head gasket.

One of the sources of economic growth is the entrepreneurship which students gain from education. Automobile technology as explained earlier provides students with different vocational skills which when utilized, they can be self-reliant, self employed, and create wealth for themselves by practicing any of the skills, thereby boosting the economy of the nation and alleviating poverty. A graduate of automobile technology can practice any of the listed skills above to sustain himself/herself for meaningful living. By so doing they create job for themselves and with wealth creation too.

\section{Conclusion}

Entrepreneurship education is very important and has the chances of equipping individual student to be able to identify business opportunity, utilize recourses with high level of skills, be able to motivate, direct, delegate other sectors to ensure an efficient synthesis of resources, he has to be exposed to entrepreneurial skills. In order to produce self-reliant and competent graduates who serve as eye openers, and who direct the nations development, entrepreneurship education should be made part and parcel of technology education, particularly automobile technology at all levels especially at technical college level where the foundation of technological, scientific cultural, political and economic development are laid.

\section{Recommendation}

Extreme poverty eradication as one of the millennium development goals can be achieved through the development of the right type of entrepreneurial skills in automobile technology among students and teachers. Therefore;

1. Curriculum should be reviewed to include entrepreneurship as part of technology education which automobile technology is an integral part of, so that the products do not only strive for self-employment and selfreliant but be self employed.

2. Entrepreneurial skills should be encouraged through the mass media.

3. Books, pamphlets, magazines and other easy to read books on entrepreneurship education should be developed by competent educationists. Such books should be made easily accessible to both present and future entrepreneur.

4. Emphasis should be place on practical institutional delivery in automobile technology programme with equal emphasis on learner's activities in very unit of the programme.

5. Every Nigerian should try as much as possible to shun all forms of corruption so as to move Nigeria forward in the scheme of national development.

\section{Reference}

Adetayo, J. O. (2009). Empowering Youth for self-reliance through entrepreneurship education. STAN $50^{\text {th }}$. Annual Conference Proceeding.

Akinboyo, G. B. (1987). "Job Creation as a Productivity Measure for Employment Problems in 
Developing Countries: The Nigeria and Holland Experience", Increasing Productivity in Nigeria, National Productivity Centre, Lagos, pp 404-41 1

Arogundade,

B.

B. (2011).

Entrepreneurship Education: An Impetus for Sustainable Development in Nigeria. Journal of Emerging Trends in Educational Research and Policy Studies (JERTERAPS) 2(1) 26-29 - Retrieved from World Wide Web on the $7^{\text {th }}$ October, 2011.

Doyin, O. O. (2004). Strategies for Improving the Teaching and Learning of Motor Vehicle Mechanic Trade in Some Selected Technical Colleges in Osun State. Unpublished Undergraduate study. Kaduna Polytechnic, Kaduna.

Elechi, C. N.(2009). Effective strategies for developing entrepreneurial skills among youth through school-industry links. STAN $50^{\text {th }} \quad$ Annual Conference Proceeding.

Margrete. E. A. (2009). Achieving Millennium Development Goals (MDGs) through teaching entrepreneurship education in Nigeria higher education. European Journal Social Science, 8 (1): 152-154

Nwagbo, $\mathrm{C}$. and Onyegegbu, $\mathbf{N}$. (2009). Enriching secondary school biology curriculum through integrating entrepreneurship activities. STAN $50^{\text {th }}$ Annual Conference Proceeding.

Oladeji, S. I. (1994). Absorption of Educated Manpower into Nigeria's Informal Sector, Diagnostic Studies Series I, NMB. Lagos.
Olatunji, I.K.(2007). Global empowerment through entrepreneurial education and creative art research. Journal of Applied Education and Vocational 2(3) 97-106.

Olutoyin, D. A. (2009). Developing entrepreneur skills through chemistry education; STAN $50^{\text {th }}$ Annual Conference Proceeding.

Ozohu, A. E. (2011). Developing Entrepreneur Skills in Biology Education: An Impetus for the attainment of Millennium Development Goals in Nigereia. In Y. A. Yahaya, S. S.; Ochigbo and D. I. Wushishi (Eds). The Role of Science, Technology and Mathematics in the Attainment of Millennium Development Goals. Book of Readings of $4^{\text {th }}$ Annual Conference of School of Science and Science Education. Federal University of Technology, Minna held at Federal University of Technology, Minna $4^{\text {th }}-6^{\text {th }}$ November, 2011. 248-252.

Paul, E. O. (2005). Entrepreneurship education in Ezema Priscilla $\mathbf{N}$, Paul Elizabeth O.; Anioke Beatrice O., Godwin A. G. Okwuolise, Chikwe, A. Eheli, Henri U. Anih (Eds) Entrepreneurship in vocational Education - Enugu OZYBEL Publishers.

Raheem, M. I. (1993)."Nigeria for Africa: A Case for Labour Export", in Oyejide, T. A. and M. I. Obadan, Applied Economics and Economic Policy - In Honour of Emmanuel C. Edozien, Ibadan Press, Ibadan.

Rama, Martin (1998)."How Bad is Unemployment in Tunisia? Assessing Labour Market Inefficiency in a Developing Country" Research Observer. 13 (1):-The World Bank. 
Ugwaja, S. I. (2010). Vocational and Technical and Development. Retrieved from World Wide Web on $9^{\text {th }}$ September.

Umo, J. U. (1996). "Introductory Overview" in J. U. Umoh (ed.) Towards Full Employment Strategy in Nigeria. National Manpower Board, Lagos.

Vandemoortele, Jan (1991). Employment Issues in Subsaharan Africa, AERC Special Paper No. 14, August, AERC Nairobi. 